\title{
Anti/pastoral Landscapes and Places in Lithuanian Literature: Looking for Paradise Lost
}

Where are you now, my old friends, the people, whom I grown up with, like with shrubs, with fields, with hills' gravel pits where are you now, and where are those fields, where are retteries, where is that high summer's sky, where is December's snow?

Jonas Mekas

Natural places, pure landscapes "untouched" by civilization have always had a special place in the Lithuanians' national consciousness. Indeed, for a hero of our prose nature is a space which he runs to from disasters of life, observes Violeta Kelertienè (Kelertiene 2006: 108). Moreover, in nature, especially in the forest the Lithuanian finds a physical asylum. I $\mathrm{n}$ the national mythology the forest was a sacred place, to some extent even a live cemetery: there are gathered his dead ancestors turned into the trees. All partisans and rebels of Lithuania who hid in the forest, found there a shelter and could successfully fight the enemy (ib.). That is why for Lithuanians the forest is not just a mystical, pagan sacred space, but also a safe haven - a peculiar synonym for the Christian paradise. Under critical historical circumstances, which threatened the survival of the nation (wars, exile, Soviet occupation, censorship), the forest, the wood (later the village was included) were the places to which people were running, where they were looking for support and shelter, and which were perceived as the lost paradises (pastoral).

Talking in pastoral terms and looking at some particular places as natural areas where everything is possible as in paradise, defines the literature of post/colonial countries and nations, notes Lawrence Buell (Buell 2005: 144-145). Moreover, this "new worlds" pastoral, in time, helped to give rise to different forms of pastoral nationalism 
on the part of the postcolonial intelligentsias, such as the wilderness cult in the USA and the Negritude movement in French-speaking Africa and the Caribbean. "Nations do generate distinctive forms of pastoral or outback nationalism (e.g. the myth of the Bush for Australia; the mystique of the far North for Canada; the iconicity of the Black Forest for German culture; the myth of the jungle for Creole cultures of Brazil, Venezuela, and other Latin American nations)" (ib. 16). The germs of unique - Lithuanian pastoral - can be found in Kristijonas Donelaitis and Antanas Baranauskas (the agro-mythical world view, the symbolism of the native soil, the idealization of work and nature) also at the beginning of $20^{\text {th }}$ century in the Lithuanian poet Maironis' texts that motivated idealistic national thinking and gave rise to the peculiar Lithuanian culture, and specific-nature based nationalism. Thus the national (Lithuanian) pastoral was formed under the influence of both: the old pagan (mythical world-view that claimed an inherent unity of the Lithuanian and nature) and the Christian tradition fortified by Maironis' lyrics.

In this way the traditional pastoral narrative "invited" the reader to either the wild, primordial oasis, akin to ancient Arcadia, or the idealized harmonious natural environment having a meaning of the Christian paradise (lost). In any case, the mentioned pastoral toponyms - they are exclusively natural, "untouched" places and landscapes providing a hope of "unspoiled" and safe excitation for all Lithuanians. According to Rimvydas Šilbajoris, nature's symbolism frequently embodies the opposition between a free, pre-war Lithuania, envisioned as "Arcadia, an ancient mythological country, a kingdom of freshness and greenness", and Lithuania, suffering from the consequences of Soviet occupation:

The Second World War shattered this pastoral scene and sent many of the best poets into exile. The Arcadian image of their previous poetry now became a paradise lost, and the poets could hardly bear to speak of anything else. Consequently, the same home landscape now left behind continued at the center of their creative effort, and the framework of nature remained as the dominant system of images. (Šilbajoris 1997: 5-6). 
Such a vision of the home landscapes and native places as a lost Christian paradise, perhaps is best reflected in the Lithuanian émigré writer Jonas Mekas' poetry collection Semeniškiu idiles (Idylls of Semeniskes):

We watched, how men, under the burning midsummer's sky,/ how woman, in colored and varied shawls, go along the swaying fields in the heat,/ breaking mowed hay swaths,- $[\ldots]$ / whether, sitting in emptied, bare autumn's fields,/ under the open and torn by winds tree,/ crouched in a broad and wornout by elder brown coats,/ popped coals, watching, how with big and humorous, wide numbers,/ happened to come and making noise autumnally, in starlings air-blasts tear mellowed, the last rowan berries $[. .$.$] / in$ rye stubble and mow down meadows/ go cows' and sheep's flocks,/ only the shepherds' fireplaces burn in the wind. (Mekas 1997: 49).

The memories of a bright and carefree past, a return to the idealized world of childhood as a kind of paradise lost as a constant literary signifier, according to Raymond Williams, means nothing else than an intention "to beat the present" (Williams 1975: 12). Such a withdrawal to an idealized childhood world and/ or the traditional Lithuanian village, which perhaps no longer exists, but which is again revived in memories and dreams is basically typical of all the mid $20^{\text {th }}$ century's emigrants' writing, e.g. Marius Katiliškis Užuoveja (The Lee), Jonas Mekas Semeniškiu idilès (Idylls of Semeniskes), Pulgis Andriušis Kitoj pusejj ežero (On the Other Side of the Lake). The discourse of retreat, a possibility to escape from "our manners", "our climate", "our age", into a literary construct is an essential/ fundamental pastoral movement, allowing us to define all pastoral narratives (Gifford 1999: 45). In this way a retreat to the world of childhood, an immersion into a state of dreams and memories in the analyzed Lithuanian emigrants' texts should be understood and regarded as a conscious literary narrative strategy, allowing the author and the reader at least for a while to forget, to escape from the historical/political/social reality that is experienced as intimidating and destructive. 
MAČAITYTE்-KASELIENE்

The perception of the lost homeland in terms of the culture/nature opposition in Lithuanian émigré writing may be seen as a response to the Soviet occupation. Collectivization, as well as the industrialization and urbanization is understood as destroying our national Lithuanian - culture. The village was not really a form of pastoral until the Second World War. At the end of the $19^{\text {th }}$ and the beginning of the $20^{\text {th }}$ century the village was a place for living and as a natural environment/landscape became an embodiment of harmonious stability and security. After the Second World War, when Lithuanian writers escaped to Germany, and later to America, it is not the forest, woods, wild landscape, but the village that is the place that is dreamed of as a lost paradise. In the middle of $20^{\text {th }}$ century the native soil, husbandry scenes, the agrarian landscape, even the village community and connections with it become symbols of "Lithuanianness". Our national culture, the national pastoral and the specific Lithuanian national self-consciousness are probably best revealed in Jonas Mekas' book Laiškai iš niekur (Letters from Nowhere):

I called my column Letters from Nowhere. But while reading all these letters I felt, that those letters were also from Nowhere. If you don't have a land, so you are nowhere./ Earth, earth's, for earth, earth, with earth, on earth, oh, earth!/ That is how my teacher, Šerniené, taught./ Neglect the land - and all cities will collapse./ Neglect the peasants - and begin to dig your last hole. (Mekas 1997: 29).

And continuous:

And farmers, tillers, peasants were, are and will be - and I will always be with you, wherever I would be: here, there, or Nowhere. There is nothing more precious and more sacred than earth, all of us mother earth, and all of you, who love her and work and eat bread in their sweat. (Ib. 145)

Thus to the land, the traditional Lithuanian village, the agrarian worldview, rural landscapes, even earthworks are ascribed not just the meaning of the nation's spiritual life, the viability of life, but also 
one's physical survival in difficult historical circumstances, as well as resistance to foreign (Russian) rule and cultural imperialism.

Like Lithuanian literary and cultural anthropologist Vytautas Kubilius has perceptively noted,

When a nation loses its state, the native land remains the last one basis of presence. The poetic mythology of the native soil, as manifestly declared the anthology "The Land" published in Chicago in 1951, is rooted in the occupied literature as a keynote of resistance, hope and sorrow (M. Martinaitis, J. Strielkūnas, J. Aputis creation). In many poetic and prose works land becomes the fundamental word, surrounded by the aureole of romantic idealization as the most important principle of Lithuanian national consciousness and culture. The emblematic homeland image legitimized by the nation's identity and agrarian overlap, not a bit affected by the country's industrialization, took on mythological depth and fundamentalism. (Kubilius 1995: 618619).

That is the emphasis of the native land mythology, where the Lithuanian is perceived as a tiller or a farmer, having an agrarian mentality. Precisely this - the unique agricultural worldview is understood as the only hope for the nation's survival in historical cataclysms. The preserved, cherished values of the traditional - nature based culture, the agrarian self-consciousness - these are the elements embodying the Lithuanians ideal, thereby becoming an opposition to the East (Russian) and the émigré writers' western culture. On the image of the native soil various national mythologies and/ or idealistic, utopian narratives, claiming tradition, national culture and Lithuanian national identity are based. Thus the land - consoling, providing the vital forces, spreading vitality - becomes the dominant pastoral image in $20^{\text {th }}$-century Lithuanian literature of emigration.

According to Stephen Daniels, national identities are coordinated, often largely defined, by "legends and landscapes", by stories of golden ages, enduring traditions, heroic deeds and dramatic destinies located in ancient or promised home-lands with hallowed sites and scenery. Landscapes "picture the nation" (Daniels 1993: 5). "As exemplars of moral order and aesthetic harmony, particular 
MAČAITYTÉ-KASELIENE்

landscapes achieve the status of national icons" (ib.). Lithuanian literature which reflects the forms of nature-based nationalisms, is not an exception. Following from what was mentioned above, the forest, fields, villages, the native land - are places, where Lithuanians could go and find shelter in destructive socio-historical circumstances. Moreover, these natural places and particular landscapes of Lithuania are actively emotionally experienced and realized as a part of individual as well as national identity:

I think that it does not matter what nature or landscape people or nations live in. What is important is what he ascribes to that landscape.

And, we ascribe a lot to our small, modest, simple landscape. We made it warm, delicate, sweet, and lyrical. We made it with our songs, with wooden ware we made it like that, with our poetry, our every move and every touch we made it like that.

And I drove through America, and looked at things, trees, works, and everything was in one dimension. No smells evoked by those trees, they are alien to me, and there are no feelings, no memories (Mekas Letters from Nowhere 1997: 121-122).

The creation of an emotional connection with the unique homeland landscape, the realization of some specific locations (places and landscapes) as pastoral - protecting, own - this is the result of various textual and cultural narratives. It is meaningful that these specific landscapes and places throughout "picturing" the nation became symbols capable of "speaking" the meanings of national and cultural values.

The importance of national pastoral images was confirmed during the second Soviet occupation when the Russification policies, viewed in retrospect, were directed at their suppression or complete elimination. According to Elena Baliutyte, in the "Soviet period" Lithuanian literature clashed with a very strong anti-nationalist campaign, primarily evidenced in the especially intensive harassments of the so-called rural prose (Baliutyte 2002). The native landscape seen as "the most important manifestation of nationalism and aestheticism" becomes highly supervised and controlled. Therefore literary censorship prescribed moving the plot into the city, writing about 
working-class themes and, most importantly - "no love, no nature" (ib. 43). However, despite such a strict control of literary and cultural life, most $20^{\text {th }}$ century literary narratives: 1) retain the images of pure, "untouched" nature (forest, woods, wild areas); 2) reiterate the symbolism of the native soil (including the land, village, rural Christian - community); 3) continue the Lithuanian cultural tradition of the rural word-view and national agrarian self-consciousness; 4) reflect nature's scenery, invoking nature-based nationalism (magical realism, nature symbolism, the Aesopian language - the main techniques that are used in this period's Lithuanian literature).

The end of the $20^{\text {th }}$ century and the beginning of the $21^{\text {st }}$ century mark radical changes not only in the Lithuanian literature, but also in the national consciousness and self-awareness. The subject of contemporary literature is a rover, a nomad, a person without place, lost in space and in time, and lost in the seared virtues. However, this "unplacedness" differs from the texts of the exiled authors, because the person of the end of the $20^{\text {th }}$ century and the beginning of the $21^{\text {st }}$ century does not find support and stability neither in the nature of the motherland, the fields of the homeland, nor in the streets of the urbanized city:

What kind of years can be, when this sort of time, then there are no years. Plague destroys years. Eats everything. And cities consumed. And port disappeared. Just Vilnius exists, says, it is still alive there and counts the years. And here are no years anymore. What years here will be, when nothing left, so from where could those years be. Villages gone into forest, trees watch through the chimneys, before burnt them as firewood, and now they grow in stove, look out through chimneys and do not see people [...] what times is this, if it's death. (Ivaškevičius 1998: $68)$.

The traditional agrarian-mythical worldview, the close connection/ identification with native soil, an ability to discover a shelter and support in nature (traditional national pastoral images: forest, woods, native fields, Lithuanian landscape) are drastically dismantled, deconstructed and/ or mocked by giving them totally opposite (the nation's death, moral failure and destruction) meanings. 
MAČAITYTÉ-KASELIENE்

The inability of the contemporary Lithuanian literary subject's to find some stable, safe, consolidating places becomes a dominant textual element on which narratives of the apocalypse are based. For today's subject neither traditional pastoral toponyms (native land, village, forest, parents homestead or his childhood home), nor the more artificial spaces constructed by contemporary culture: city, hospitals, museums, streets, etc. provide security. Furthermore, all spaces, like the city itself are experienced as mysterious, frightening, unsafe, aggressive, or even hostile to human beings:

S. had to decide quickly whether to stay for the night in the desert, which frighten him, or to go to town, which did not seem safe either.

However, he decided to go to town. Even though there are Vulture and Nobody, but these two creatures frightened him less than the Beast lurking somewhere. (Janušaitis, Lideikis 2005: 56-57).

It seems that at the turn of the $20^{\text {th }}$ and the $21^{\text {st }}$ centuries there is no place to which as into a Christian paradise lost or an ancient mythical country of dreams and illusions - an Arcadia - to run and which would provide a soothing refuge, harmony and shelter.

What causes such apocalyptic tendencies and the disruption of the pastoral vision? Like Indre Žakevičienè notes, "the symbol of agrarian culture that marks the spirit of those living in Lithuania is still visible but hardly described" (Žakevičienè 2007: 168). Today we are experiencing a specific - "a new displaced persons" situation. There is a paradox: we feel labelled, not only pulled away from land, but also displaced - of our own free will; the physical body obeying the laws of the age of globalization, but the spirit still vaguely longing for the still existing yet unfashionable Arcadia (ib.). "In our postmodern age we dismiss this Arcadian image as an idealized pastoral myth", claim western literature's and culture's researchers (Gifford 2006: 3). It could be anticipated that these changes, brought about by globalization and the western culture are especially deeply and painfully experienced in post-colonial Lithua- 
nia, where the cultural tradition, as well as national values were cherished for several centuries up till now.

However, the analysis of contemporary Lithuanian literature reveals that talking in pastoral terms is impossible after materialism, alienation, the loss of contact with nature, with the surrounding environment in general. The loss of space, fluttering in various nonplaces, the inner emptiness, the existential "gap" is visualized through frightening dreams and nightmares:

Decided to change us. Set this forest on us. We flop down from plague, from starvation and from death, but neither starvations kills, nor the forest fells lack of eating. Land feeds it, but not us anymore. There are no mysteries anymore. If the tree watches through the chimney - what can be mystery? Just Vilnius still holds, and where he is - I already don't know well. We are going to Vilnius too, just like you, but we lost our direction. Or to be more precise, we know the direction, in the East Vilnius was, when we started to walk towards it, but is it still there - I cannot tell, because everything has changed so drastically, that we could have passed through. Lawks some barefoot refugee soldier would tell us what kind of place this is. He knows even less, because until the war he hasn't seen it even in his dreams. (Ivaškevičius 1998: 69).

In contemporary Lithuanian literature the village is not the object of visualization or idealization and exists only peripherally. The land, the forest, the woods, the native fields, the village, the rural landscape used to be the basis for the Lithuanian national identity, in the $21^{\text {st }}$ century become objects of utility or a source of profit. The struggle between the traditional forms of "Lithuanianness" (Lithuanian nature's child, ploughman, tiller) and the western culture's innovations; the interface between the Lithuanian's closure, stability and openness brought about by globalization determine the state of uncertainty, fear and emptiness in contemporary Lithuanian literature.

It is meaningful, that this state of confusion, uncertainty, loss and obscurity is narrated not only in literature but also in the newest photo album Unseen Lithuania (2009) as well: 


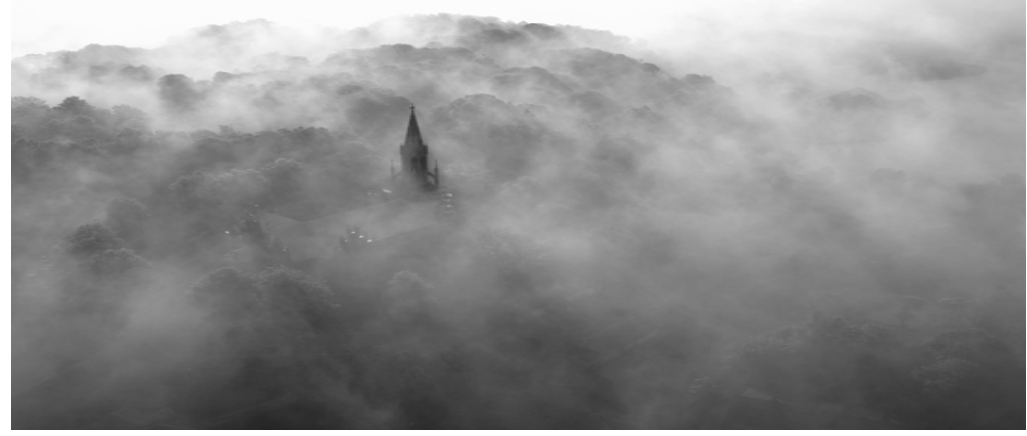

Landscapes drowned in fog become a reference to the obscure, unstable, vanishing (and maybe the already vanished?) traditional Lithuanian national identity. Efforts to reflect the national identity in the changed environment; torn between the traditional (national) culture's nationalist forms and the obligation to escape from it have resulted in a "picture" of Lithuania as a mystical, fantastic, an almost unreal place, a non-place, to be precise.

Contemporary Lithuanian literary narratives reflect similar, basically identical meanings. Changes in both the historical and political but also the cultural context (the restoration of Independence, the European Union bringing western culture, the processes of globalization, etc.) call into question the effectiveness of the traditional pastoral imagery:

Does anybody know it? Lithuania? Not anymore.

Everyone, who knew, left.

Here nobody knows her anymore. (Ivaškevičius 1998: 72).

I should look for a different - fragrant and not outworn Homeland's. I should have to tame it little by little, later - take care of it and cherish it. For that, new one, would not be enough just a doggy affection and loyalty. (Jakučiūnas, 2007: 81).

Lithuania, with traditional - "old-fashioned" - mythologies is unrecognizable, unknown, alien to today's modern person. Contemporary texts emphasize the "wastage", disability, inefficiency of traditional 
pastoral images and places. Moreover, the predominant mock pastoral or anti-pastoral narratives in Lithuanian literature indicate the necessity of revision, transformation, and/or renewal:

Lithuania is the shoes. It is important to well-worn it on time. (Ivaškevičius 1998: 75).

Clapped with palm through the floor, solid floor, it was to walk. "I would only stroll after you, - said for home. - I would not go anywhere from you, but I need to leave just once, at least one cartel like this, when you don't know, whether you comeback [...] "I would stroll after you", but it is necessary to leave just once, thought again. - You are good animals (livestock), but the most important true, you, old man, look after the home, maybe someday we will stoke, stoke, old man, stoke again if I return.

(Ib. 76)

Traditional pastoral images (home, livestock, Lithuania itself) are realized as useful, precious, having "served" us for centuries (the significance of shoe's), but already threadbare elements ('It is important to well-worn it on time"). Their examination/testing and review is unavoidable ("it is necessary to leave just once") in newly changed - geopolitical, multicultural - circumstances. In contemporary texts alongside traditional pastoral images the emerging irony precludes the reader's empathic attitude to the text. Thus a nonemotional, distanced audience-text relation is promoted.

These peculiarities: 1) an invitation to think, a deeply critical attitude towards traditional pastoral images; 2) their examination/ testing in contemporary changed (social, geo-political, cultural, historical) settings. Thus traditional pastoral images in contemporary literary narratives are placed next to pop-culture, innovations brought by globalization, western cultural elements); 3) the desire not to deny drastically, destroy or "get rid of" (like in the typically postmodern anti-pastoral western literature and culture), but to reconsider traditional pastoral images and the national cultural elements, and maybe refresh them again, return to them ("you, old man, look after the home, maybe someday we will stoke, stoke, old man, again stoke, if I return") allow to state that contemporary Lithuanian 
literature is not dominated by the destructive, negative, apocalyptic anti-pastoral but a version of the new - complex pastoral ${ }^{l}$.

The narrator of the contemporary Lithuanian writer Gintaras Beresnevičius' novel Paruzija (2005) speaks about significant changes not just in the external (in social, geo-political, cultural, historical) reality, but also in the national consciousness and Lithuanian self-awareness:

- Today busy with nonsense we didn't notice that we exist in an island. We exist in politics, economics, Europe, moreover in the "Centre of the Europe", but we, thanks to God, are aside from terror. Of course, this may be just the matter of days - absurd strokes of terror hit in totally unexpected and in most innocent places. But today we are in an island [...] we got to the bay of the history and became an island after all. With the island's mentality. (Beresnevičius 2005: 123).

Today's texts are based on a desire to find some "fresh", pure, "clean", unspoiled places - natural areas that the $21^{\text {st }}$ century's Lithuanian nation could identify with. Thus Lithuanians are represented like different others, having an island mentality. Such representations mark the writer's aspiration for the nation that has missed its own identity, is unable to find any stable values.

The island as pastoral image of Lithuania is also reflected in the $21^{\text {st }}$ century's photo narratives (Jovaiša 2009):

${ }^{1}$ Complex pastoral - Leo Marx's "invented" term. Opposite to sentimental pastoral/ pastoral of sentiments (that is inherent in Lithuanian émigré texts, as well as the $20^{\text {th }}$-century traditional literary/cultural narratives) this kind of pastoral is often critical, affecting the reader's thoughts, but not feelings. These old and new pastoral images and the newest forms of the nation's self-consciousness have the purpose of revising/examining traditional national pastoral images and/or traditional narratives of the sentimental pastoral. Therefore, according to L. Marx, the complex pastoral acts as some particular "reaction power, cutting its idyll" (Marx 1964: 70). 


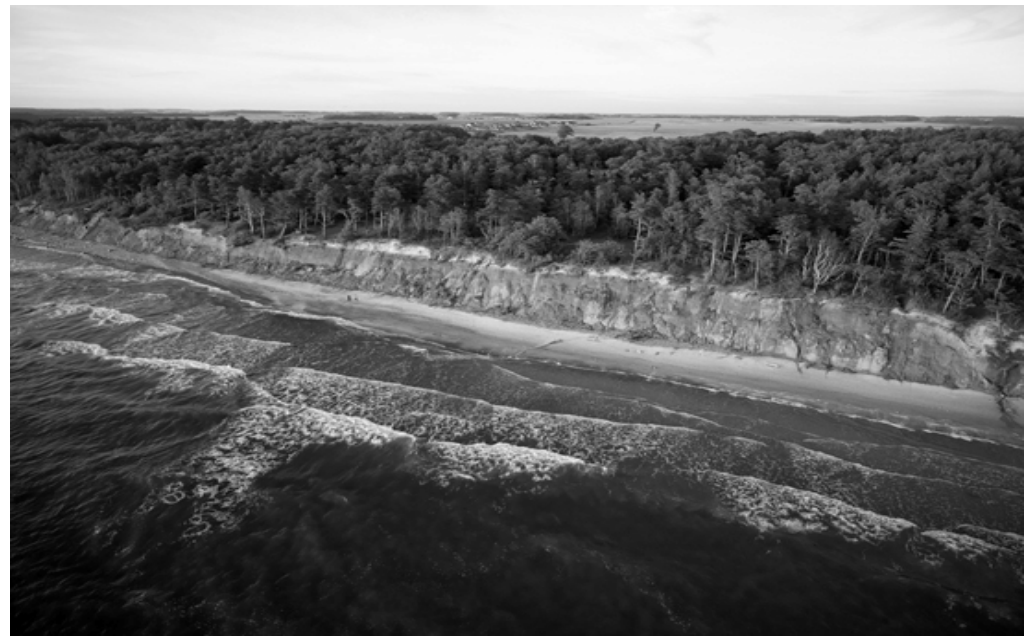

Natural, "untouched" landscapes reveal the intention of restoring the lost pastoral. An island as a closed, protected space becomes a place of delight. "Pastoral, in fact, is that other place which the human mind ceaselessly constructs as a place apart from the everyday's pressing actualities", notes Stephen Watson (Watson 2005: 148). Thus in traditional pastoral narratives and in the contemporary literary narratives the basic objective remains the same - to provide consoling dreams about the nation's existential succession, its identity, oneness and individuality.

One of the best known and most popular Lithuanian writers Gintaras Beresnevičius has probably the best explained the "mission" of contemporary art:

And still the responsibility remains - to name the current condition. It is not named, I emphasize that; what is more, "namings" may and should be done differently. Naming encourages, I would say, social acuity. Naming provokes discussion. Naming is important, that we could exist in time and space - without political constituents. Intellectual while provoking must name the present, from it's positions - past, that is history and future [...]. 
Fights take place not under the carpet, but deeper than whiles' paths; intellectuals' task, in fact, - to be anesthesiologists. To offer dreams because otherwise it is too horrible. (Beresnevičius 2003).

\section{References}

Baliutytè, E. 2002. Laiko ịkaitè ir partnerè: lietuviu literatūros kritika 1945-2000. Vilnius: Lietuvos literatūros ir tautosakos institutas.

Beresnevičius, G. 2005. Paruzija. Vilnius: Tyto alba.

Beresnevičius, G. 2003. Intelektualas: misija. Metai. Vol. 3.

Buell, L. 2005. The Future of Environmental Criticism: Environmental Crisis and Literary Imagination. Blackwell Publishing.

Daniels, S. 1993. Fields of Vision: Landscape Imagery and National Identity in England and United States. Polity Press.

Gifford, T. 1999. Pastoral. London and New York: Routledge.

Gifford, T. 2006. Essays in Post-pastoral Practice. Athens and London: The University of Georgia Press.

Ivaškevičius, M. 1998. Istorija nuo debesies. Vilnius: Lietuvos rašytojų sajungos leidykla.

Jakučiūnas, A. 2007. Tévyne. Vilnius: Lietuvos rašytojų sajungos leidykla.

Janušaitis, E., Lideikis, M. 2005. Nuo Roko iki Abelio. Kaunas: Naujasis lankas.

Jovaiša, M. 2009. Neregèta Lietuva. Vilnius.

Kubilius, V. 1995. XX amžiaus literatūra. Vilnius: Alma littera.

Marx, L. 1964. The Machine in the Garden: Technology and the Pastoral Ideal in America. New York: Oxford University Press.

Mekas, J. 1997. Laiškai iš niekur. Vilnius: Baltos lankos.

Mekas, J. 1997. Semeniškiu idiles. Reminiscensijos. Vilnius: Baltos lankos.

Kelertienè, V. 2006. Kita vertus. Vilnius: Baltos lankos.

Šilbajoris, R. 1974. An Intelectual's Encounter with Nature - Modern Trends in Lithuania Poetry. Lituanus. 20(2): 5-14.

Watson, S. 2005. Bitter Pastoral: The Meaning of the Cedarberg. English Academy Review. Vol. 22: 146-159.

Williams, R. 1975. The Country and The City. New York: Oxford University Press.

Žakevičienė, I., Višomirskyte, V., Ragaišienė, I. 2007. Ekokritikos akivarai. Kaunas: Vytauto Didžiojo universiteto leidykla. 